Mr. J. L. Pretorius describes an experiment carried out by the Dutch Reformed Church Mission in August and September 1947. The aim of the experiment was to devise means for maintaining the cohesion of African society in spite of the changes brought by education; to this end it was decided to teach adults the same things that their children learnt, to use the same teachers, thus making the teacher a link between parent and child, and to teach parents and children in the same school building-though at different times-so that the school should become the educational centre for the whole community. During the period of the experiment 803 schools were conducted by 820 teachers and the enrolment of adults was 10,780 men and $I 2,991$ women. These were grouped into three classes: illiterates, poor readers, and those with some education. The experiment had a measure of success in that about one-tenth of the illiterates learnt to read the vernacular; the best results were obtained with the third group, but the group as a whole appeared to derive interest and stimulus from the teaching. A more ambitious project was carried out in Kalumbu, Lelongwe district, where, with the co-operation of the District Commissioner and the provincial education officer, lectures were given by government technical officers and handwork classes were arranged. In addition, communal work on cleaning out and sinking wells, and on repairs to church and school buildings, was carried out. A bookshop was installed at the centre, and books to the value of $f_{24}$ were sold. The results of these experiments provided useful guidance for further work-especially in methods of teaching reading and writing and in training teachers in the technique of teaching adults.

\title{
Place-names in the Uluguru Mountains, Lake Province, Tanganyika Territory
}

THE prefixes of place-names in use among the Waluguru present features of interest which may be summarized as follows:

The prefixes commonly occurring are: MU (M), LU, KI, MA, VI, NYA; more rarely KA and LI.

(a) MA and vi, being plural prefixes, indicate always a quantity, e.g. MASALAWE- a place with many white stones on the surface; vitaluLA - a place where many mtalula trees grow; MA NGAYE-a place of much sickness. The plural prefix for trees being always, grammatically, $\mathrm{MI}$, in place-names it always, or nearly always, occurs as vr.

(b) $\mathrm{KI}$ and $\mathrm{MU}(\mathrm{M})$, being singular prefixes, indicate a single object or place, e.g. a tree, standing alone, KIKUYU - near that single mkuyu tree; KIBWE - near that big stone; KIDEGE -on that special hill or hill-top. The same for MU (M): MTAMBA- where that mtamba tree stands. But in some cases $\mathrm{MU}$ indicates a more extensive area, especially when used in conjunction with a verb, e.g. MUHAME-a deserted place; MUHALE-a refugee country; MBAKANA - a boundary river. There remains a difficulty in connexion with $\mathrm{KI}$, used frequently to indicate a place where a certain kind of grass grows: one would expect the plural form vi.

(c) LU; although not very clear, the meaning seems to be 'a very large country' (cf. Bu in BuGANDA; Africa, Jan. 1948, p. 51). A river flowing through the country takes the same name. But the contrary may also be true, i.e. the river-name takes the prefix $\mathrm{LU}$ and the name is given to all the country on the two banks of the river. It is a fact that very many river-names have the prefix Lu. But what, in the latter case, will be the meaning of Lu? I could get no information on this.

(d) NYA; I suspect the meaning of this prefix to be 'high', 'up', for two reasons: (1) The Kiluguru word for 'high' is $u$-cha-nya. (2) Place-names with prefix NYA refer to high places, e.g.

Nya-ngoma-the ngoma on the hill.

Nya-kiti-the matambiko in the mountain forest.

Nya-miduma-forest on the hill, where the wind roars (kuduma). 
x. Some place-names may have as many as two or three prefixes: e.g. Nya-mi-gudu, Ki-nya-ki-ti, Nya-lu-baha.

2. There are two suffixes: Ro and SI. The meaning of Ro is very uncertain: SENERo, TENGERO, CHOHERo. The meaning of SI (TSI) may be an abbreviation of MAZI-water, because we find it always in names of rivers.

3. It must be understood that there are many place-names without any prefix or suffix. Communicated by C. Vermunt

\section{Spelling of African Place-names on Maps}

The Linguistic Advisory Committee of the Institute, in consultation with the Place-names Committee of the Royal Geographical Society, has given much consideration to the difficult problem of the spelling of African place-names on maps. The matter was also discussed at the Deuxième Congrès de Toponymie et d'Anthroponymie in Paris last year, and a recommendation on the subject was recorded at the Conférence Internationale des Africanistes de l'Ouest at Bissau in December last. The complete lack of uniformity, or even of recognized principles of orthography, is a source of confusion and difficulty for students no less than for travellers. In a recent number of the Bulletin of the School of Oriental and African Siudies (vol. xii. 3 and 4, 1948), Dr. A. N. Tucker states the existing problem, reviews the various attempts which have been made periodically since 1745 to standardize the representation of geographical names, and describes the emergence of a new factor in the problem as it concerns Africa, in the wide adoption of a standardized orthography (the Institute's Africa orthography) for vernacular languages. Dr. Tucker considers that the attempt to introduce phonetic characters on maps would be premature, and recommends that where the standard alphabet of a language contains phonetic characters or letters with diacritics, a form of romanization should be worked out for use on maps; he suggests that, in general, the spelling recognized by local authorities should be followed for place-names on maps, and refers to a recommendation of the Congrès de Toponymie that the names adopted for places in West and Equatorial Africa should be those used by the natives of those places.

\section{Land Conservation and Utilization}

GovernMENTs in all parts of the world are becoming increasingly aware of the urgency of the problems connected with land conservation and use, particularly in tropical and subtropical areas. The numerous conferences of experts, the carrying out of soil surveys, and the establishment of research organizations and agricultural bureaux are indications that the fundamental importance of these problems is not ignored. In June of this year a conference on tropical and sub-tropical soils was held at the Rothamsted Experimental Station, England, when the Under-Secretary of State for the Colonies welcomed guests from the United States, France, Belgium, and Holland. The committee for Colonial Agricultural, Animal Health, and Forestry Research organized conferences at Nairobi in 1946 and 1947, at which improved arrangements for agricultural and veterinary research in East Africa were initiated and the need for a comprehensive soil survey was stressed. During 1947 a soils sub-committee was appointed to specialize in soil science research. In West Africa much attention has been paid in recent years to problems of agricultural production. Research into improved methods of rice production is being carried out in the Gambia, and the most extensive soil survey yet undertaken in the Colonies is shortly to be started in the Gold Coast. The survey will cover an area of $5 x, 000$ square miles, largely tropical forest and savannah. Six Europeans and 120 trained Africans, as well as African labourers, will be employed, since the intention is that the survey shall be carried out by the inhabitants of the Gold Coast, and the first year's work will consist largely of training African staff. 